\title{
Social work education in the Middle East and North Africa: Students' perspectives at 13 universities in 10 countries
}

\author{
Qusai A Ibrahim (PhD)
}

Assistant Professor, Intermediate College for Security Studies

AL-Istiqlal University Jericho - West Bank - Palestine

Khalid M. Hreish (PhD)

Al-Quds University, Palestine

Khalid S. Hantoosh (PhD)

University of Baghdad, Iraq

Odessa Gonzalez Benson (PhD)

University of Michigan, USA

Ayman A. Galalh

Al-Imam Muhammad Ibn Saud Islamic University Saudi Arabia Khalil I. AL-Halalat

The University of Jordan

Lubna M. Aladayleh

Al-Balqa Applied University Jordan

Emadeldeen A. Shalaby

Umm Al Qura University Saudi Arabia

Hazem M. Matter

Helwan University Egypt

Yagoub Y. Al-Kandari

Kuwait University Kuwait

Sokina A. Hashim

Sana'a University Yemen

Mansour A. Eltaef

University of Tripoli Libya

Samar S. Sofy

Fayoum University Egypt

Mona B. Abdel Meguid

Sultan Qaboos University Sultanate of Oman

Nabila N. Daqaq

Bethlehem University Palestine

Mohammed B. Elardi

President of the Moroccan Association of Social Workers Morocco

Ramadan K. Sharaia

Statistical Analyst Palestine

Hassan A. Al Madhani

Social Researcher Sultanate of Oman

Talaat H. Braz

President of the Yemeni Association of Social Workers Yemen

Magda F. Sorur

Qatar University Qatar 



\section{Social work education in the Middle East and North Africa: Students' perspectives at 13 universities in 10 countries}

\section{Abstract}

Efforts for improving social work education (SWE) in the Middle East and North Africa aim to address complex development issues. Using quantitative and qualitative approaches, this paper examines students' perceptions of SWE, surveying 810 students in 13 universities in 10 countries: Egypt, Iraq, Jordan, Kuwait, Libya, Morocco, Oman, Palestine, Saudi Arabia, and Yemen. Results indicate that primary obstacles pertained to externally-oriented realworld application of SWE, while secondary were internally-oriented university factors (ie. libraries, assessments). Findings suggest that advances in SWE should occur not only within universities, but also substantively and holistically across welfare institutions and systems in the MENA region.

\section{Key words}

Arab social work education, educational reform, international social work education.

\section{Introduction}

Scholars in the Middle East and North Africa (MENA) region, as well as other nations globally, are calling for modernising and improving social work education (SWE) and practice in ways that align with local practice (Hassan, 2010; Ibrahim, 2015, 2018; AlMakhamreh \& Libal, 2012). The professionalization of social work in the MENA region is growing and currently undergoing complex and profound shifts (Al-Makhamreh \& Sullivan, 2013). Efforts in the SWE and professional domain are particularly crucial in light of dramatic shifts in social, economic, and political conditions (Soliman \& Elmegied, 2010; Al-Makhamreh \& Libal, 2012). Social work educators and scholars also convene regularly at regional conferences, which yield rich insights and discussions.

However, the research is predominantly presented in Arabic and discussions have largely been confined to the scholarly social work community of the MENA region. This disconnectedness stifles exchange of knowledge, which is particularly critical given the globalising vision of SWE. In the global north, meanwhile, there are increasing calls for international perspectives in SWE in response to globalisation, migration, and other global issues. In the United States (U.S.) particularly, this has led to an increased focus on intercultural 
competence (Dominelli, 2010; Lyngstad, 2013; Small, Sharma \& Nikolova, 2015; Alsahow, Paris, Sayed, et al., 2019). International field education or practicum placements is also increasing, requiring preparation and collaboration between schools (Baum, 2012; Small et al., 2015). These cross-national academic exchanges and connections foster cultural competence among students and institutions. As SWE continues to grow towards culturally competence in a global sense via academic exchanges and connections between academic communities in MENA region and waestern nations, scholars call for 'reciprocal understanding' that meaningfully incorporate guidance from MENA scholars, rather than one-way interactions (Alsahow, Paris, Sayed, et al., 2019).

Studies of SWE in the MENA region tend to focus on cultural and religious dimensions (i.e., Al-Makhamreh \& Libal, 2012; Sloan, Bromfield, Matthews \& Rotabi, 2017), but fewer studies focus on institutional aspects, such as teaching methods, libraries, and linkages of curricula and SWE to practice institutions wherein social work graduates would work. Moreover, the perspectives of social work students from the MENA region are under-examined (Ewiess, 2005; Mokhtar, 2006). MENA-based studies of SWE often focus on educators, researchers, and administrators (i.e., Ibrahim, 2017); while studies of SWE that focus on students' perspectives usually occur in the U.S., Ireland, and China (Cook-Sather, 2002; Lammers \& Smith, 2008; Arseneau, 2015).

Drawing upon both quantitative and qualitative approaches, this study aims to help fill gaps in knowledge about student perceptions about SWE in the MENA region. We examined student perceptions of obstacles in SWE, using and analysing a survey of students $(n=810)$ in 13 universities in 10 countries in the MENA region.

\section{Social work education in the MENA region}

Several scholars have shared perspectives, analyses, and critiques on the multifaceted obstacles to SWE, discussed subsequently in terms of curricula, field education, faculty, and public perception of social work. Curricula and training methods have not been updated in the MENA region for a quarter of a century, and have not been able to keep pace with modern developments and trends (Ewiess, 2005; Faramawy, 2005). In terms of field education, local SW organisations cannot accommodate the increasing numbers of students, and there is a lack of experienced supervisors (Soliman \& Abd Elmegied, 2010; Hassanain, 2014; Abd Al-Hamid, 2003; 
Faramawy, 2005; Awawda, 2011; Al-Imam, 1998). Another major area of concern in the MENA region is the lack of faculty members who specialise in social work (Ewiess, 2005), leading to non-social workers teaching, particularly in Egypt (Al-Deeb, 2005; Soliman \& Abd Elmegied, 2010). Some scholars in the MENA region have found that people in the community do not have an accurate understanding of the social work profession and its relevance (Abdul Maguid, 2014; Al-Halalat, 2015; Al-Deeb, 2005; Ewiess, 2005). This understanding of the social work profession in the MENA region is perhaps not globally uncommon, as social workers are perceived to be implementing harsh policies, rather than doing important work for the benefit of individuals and families.

\section{Student perspectives}

Academic literature, as well as practice-oriented discussions, have largely originated from perspectives of educators and institutions. Students offer an alternate perspective compared to that of faculty, administrators, educators, and scholars (Lammers \& Smith, 2008; Arseneau, 2015). The local context and everyday experiences of students are rapidly changing, and gaining students' perspectives connects academic scholarship and institutions to current, relevant, and on-the-ground realities. Student outcomes in education are central to educational quality; thus, student insights are key in assessing current SWE, and in informing efforts to improve it (Cook-Sather, 2002; Lammers \& Smith, 2008).

There have been some studies of social work student perspectives in the MENA region, but those were typically smaller in scale, conducted with smaller numbers of respondents, in one country or one university, or with a more specific area of study (for example, field instruction). Examples are the studies by Abd Al-Hamid (2003) in the UAE, and three studies done in Jordan, by Al-Adayleh \& AlHadedy (2013), Al-Halalat (2015), and Awawda (2011), all of which were published in Arabic and not more widely accessible. Studies based outside the MENA region have illustrated how student perspectives can provide a fundamental and specific insight on educational processes and outcomes (Cook-Sather, 2002; Lammers \& Smith, 2008; Arseneau, 2015). The work of authorizing student perspectives is essential because of the various ways it can improve current educational practice, re-inform existing conversations about educational reform, and point to the discussions and reform efforts yet to be undertaken' (Cook-Sather, 2002). As educators comprehend and 
examine learning in terms of the top-down and prescriptive starting points, students provide a view of the process and outcomes from the bottom-up. Their views show how learning and instruction happen from the receiving end, and their perspectives often reveal what is missing, contradictory, or divergent.

\section{Methods}

To examine student perspectives, a questionnaire was administered to a non-probability sample of social work students $(n=810)$ in 13 universities across 10 countries within the MENA region: Egypt, Iraq, Jordan, Kuwait, Libya, Morocco, Oman, Palestine, Saudi Arabia, and Yemen. The questionnaire asked respondents to report perceptions about obstacles in SW programs, and consisted of 139 substantive items in 12 domains of SWE. The survey had 12 domains (see Table 3), each containing 12 items, with the exception of the domain of 'quality of student assessment' which contained eight items and the domain of 'text books' which contained 11 items. Examples of items are listed under their respective domains, in the results section below. For each of the 139 items across the 12 domains, the questionnaire used a three-point Likert scale: 'disagree', 'to some extent' and 'agree,' to assess the extent to which students agree or disagree with a given item. -The questionnaire was developed by social work educators and researchers, some of whom are coauthors of this paper, drawing upon experience, direct knowledge, and expertise in teaching and researching social work in MENA universities. The survey was externally reviewed by five experts in the field, who were faculty members in five different universities where data were collected and peers of authors of this study. The reviewers conducted independent reviews and gave feedback and recommendations for revisions and improvement to the survey prior to implementation. To conduct this study and data collection, written approval of research processes and protocols were obtained from the dean/chairman of the social work department of the university. Steps were implemented to ensure participants' informed consent; researchers explained to prospective participants the importance of the research and its objectives, the voluntary and confidential nature of participation, and that there would be no consequences if they decided not or stop participating.

Convenience, non-probability sampling was used for selecting the 13 universities and research participants. Drawing from the principal researcher's network, SW programs across the MENA 
region were identified, and administrators were contacted to discuss the research and to gain consent for participation. One social work faculty member in each participating university was assigned to be research associate for data collection. Research associates administered the questionnaire in classrooms and in forums appropriate for that particular university setting.

To analyse data, we conducted quantitative summary statistics to determine ranking or ordering of items in the survey. Second, we qualitatively analysed these rankings thematically to conceptualize resultant SWE domains. The ordering of the 10 domains based on surveys were qualitatively examined for substantive themes or patterns based on clustering of domains.

Upon analysis, researchers excluded two domains in the final thematic findings, thus moving from 12 to 10 domains. The first domain excluded was 'interaction of the profession with community issues:' researchers determined that items in this domain had substantial overlap with items in other domains, particularly these three domains: societal recognition of the profession, social workers post-graduation, professional practice institutions. The second domain that was excluded was 'students of social work': researchers determined that an assessment about students as surveyed by students themselves runs the risk of being partial. Furthermore, the items in this domain was determined by researchers to be subsumed into or overlapping with the other domains. For example, for the domain 'interaction of the profession with community issues' that was excluded, there were items for that domain that researchers analyzed to be overlapping with some items in the domain of 'societal recognition of the profession.' As another example, for the other excluded domain 'students of social work', 'students' grades' as item in this domain was similar to items in the domains and 'social workers post-graduation' and 'quality of student assessment'. The researchers or authors examined the ranking of these two domains, "interaction of the profession with community issues' and 'students of social work,' and determined that excluding them did not compromise the substantive themes presented as final findings. In other words, the ranking of the two excluded domains were thematically/substantively applicable to the final findings presented. A total of 10 domains were thus included in the final thematic findings.

Respondent characteristics. As shown in Table 1, the majority of respondents in the sample was female, less than 25 years of age, 
and single, characteristics that reflect a typical social work student in the MENA region. Approximately one-third of respondents were students with an undergraduate education, which makes up the bulk of SW students in the region; the rest of the respondents were graduate students (masters, doctoral, or a combination). Table 2 provides description of the 13 universities in the sample: number of students, number of faculty members, year of establishment, number of instruction hours, student-to-faculty ratio. Representation in the sample was greatest, comprising $31 \%$ of student respondents, were from the two largest universities in our sample. These two Egyptian universities have a combined total student population $(11,224$ students) that is about 20 times more than the average student population for all the other universities in the sample (ranging 60 to 500 students), except for the university in Saudi Arabia (5870 students).

\section{Results: Obstacles to SWE by rank based on student perspectives}

We present a conceptual framework with three broad themes for obstacles to SWE in the MENA region, based on ranking by domain according to student perspectives, detailed in Table 3.

Theme 1: Externally-oriented real-world application of social work education

The four most problematic domains in SWE in the MENA region, based on respondents' perceptions, were thematically conceptualized as pertaining to "Externally-oriented real-world application of social work education." This theme can be defined as those SWE aspects that connect the substantive component or content of SWE to relevance to institutions wherein social workers are employed, to demands or needs in the community, and to relationships or links between social work and other institutions, such as governmental agencies, civil society and private agencies. Enumerated below are four domains ranked according to results.

Societal recognition of the profession (mean=2.35): level of government funding of and subsidies for the profession; public awareness of SW and its role; participation of social workers in nongovernmental organisations; and support for establishing professional SW organisations.

Field practicum education (mean $=2.33$ ): quality of supervision; professional expertise of the administrators; importance given to field practicum as part of the academic curriculum; supervisory relationship; planning by field practicum administrators; 
links between theoretical knowledge and field practicum; selection of field practicum institutions; and links between field practicum, students' needs, and the labor market requirements.

Social workers' post-graduation (mean=2.32): employment; specification of social work tasks and roles in various areas of professional practice; regulation of non-specialists in social work; and level of professional performance for social work graduates.

Professional practice institutions (mean $=2.31$ ): student visits to practice institutions; non-specialists as managers; communication between faculty members and directors of social work agencies.

\section{Theme 2: Curriculum}

Students in our sample identified the following items of interest for 'Curriculum' (mean=2.30) as domain: applicability of SWE curricula with the reality of professional practice; review of curricula on a regular basis for keeping pace with contemporary problems and with the labor market; skills development opportunities; and training in social work theories. Thus, students had less concern about skills development and theoretical components of the curriculum, while practice relevance was found to be most challenging.

\section{Theme 3: Internally-oriented university factors to SWE}

The five domains of SWE that students ranked least challenging was conceptualised collectively as 'internally-oriented university factors' This theme can be defined as those SWE aspects that relate to the process component to SWE, or how universities and educational systems conducts or implements education. Whereas the first theme is concerned with the substantive or content of SWE and relevance to application, the third theme is theorized as more related to the ways in which that substance or content is imparted to students via university resources and mechanisms. Enumerated next are the five domains and their respective substantive items, based on ranking.

Teaching methods (mean=2.29): diversity in teaching methods and lectures; availability of computer labs; modern technology for lectures; flexibility and responsiveness to students; the existence of negative aspects in the teaching of research methods and their applications; availability of buildings and establishments for SWE; and encouragement of student innovation to help promote discussion.

Textbooks (mean =2.29): planning and selection of topics to be studied from textbooks and other education materials; quality and originality of social work scientific literature. 
Library and resources (mean $=2.28$ ): availability of a library dedicated to social work; availability

of modern literature in social work; administrative procedures for borrowing books and accessing human resources in the library; availability of modern technology in the library; and availability of other resources, such as photocopying, scanner machines, and an advanced indexing system.

Student assessment (mean=2.7): objectivity in the admission of students; diversity in examinations; scientific bases for examinations; time allotted for student assessment.

Faculty (mean=2.5): number of faculty members from other disciplines teaching social work subjects; continuing education and training for faculty; accountability; use of modern technology.

\section{Discussion}

Overall, the results showed three broad themes around obstacles in SWE in the MENA region, as

perceived by the social work students in the sample. Of the 10 domains, the four with the highest ranking were themes that pertained to externally-oriented real-world application of social work education. The six SWE domains with the lowest ranking pertained to internally-oriented university factors, such as teaching methods, textbooks, and library resources. Ranked between those two themes was the curriculum, a singular domain that links the externally- or practice-oriented and internally oriented sides of SWE. The heart of the curriculum is the critical connection between the classroom and the real-world application.

Thus, SWE factors that students found more problematic were those related to the real-world application of social work, compared with institutional or internally-oriented factors. Our findings suggest that students perceived their education to be insufficient to face realities in the community as social workers. It is notable that field practicum was considered more concerning than teaching methods in a traditional classroom setting. Our findings align with those in a study by Al-Adayleh \& Al-Hadedy (2013): in one university in Jordan, students in a field practicum perceived skills development as most challenging, more than the academic component.

Findings in this study are consistent with calls for comprehensive reform in SWE in MENA universities-reform that focuses not only on institutional factors such as textbooks and assessments, but also on educational elements that directly apply to 
social work practice and outcomes in the context external to the university. Our findings confirm other assessments of SWE in the MENA region, and calls for improvements. Practice strategies taught in SW programs in the region have failed to keep pace with contemporary problems or to remain relevant to real-life issues, as found in studies in Egypt (Hamza, 2006; Al-Zobair, 2009), Botswana (Osei-Hwedie, Ntseane \& Jacques, 2006) and Jordan (Al-Adayleh \& Al-Hadzobedy, 2013). Hamza (2006) called for a focus on technical training and skill development in SWE, as well as a reassessment of curricula, including continuing education for practitioners. Mansour \& Hassan (2008), meanwhile, highlighted the role of institutions such as social work NGOs in providing support and resources to social work in the MENA region.

Insights from this study also raise questions about a social work model based on perspectives from the MENA region. Findings point to a disconnect between social work education and practice in the MENA region as perceived by students, and this may be attributed to the SWE system's basis on the Western-more specifically the American-model, as some scholars have examined (Al-Shuaibi, 2005; Mokhtar, 2006; Soliman \& Abd Elmegied, 2010; Megahead, 2016; Al-Makhamreh \& Libal, 2012). Implementing Western standards without critical assessment produces issues of ethics, cultural competence and efficacy (Ferguson, 2005; Holtzhausen, 2011; Lyngstad, 2013; Sloan et al., 2017). Within SW curricula and education, the integration of culturally competent practice requires that the field be carefully and thoughtfully introspective, so that such integration is not only effective but also appropriate and sustainable (Alsahow, Paris, Sayed, et al., 2019). Among the most important problems facing social work practice in developing countries are the theoretical assumptions and models of Western practice, which may not suit country- or context-specific conditions and problems (Osei-Hwedie et al., 2006). Meanwhile, there is a lack of Arabic scientific literature (Al-Deeb, 2005; Kokaliari et al., 2016; Mokhtar, 2006) written by social work faculty members to provide substantive content for MENA-specific SWE (Al-Shuaibi, 2005; Mokhtar, 2006). Furthermore, the diversity and homogeneity in the MENA region further complicate and nuance efforts (Alsahow, Paris, Sayed, et al., 2019). Our findings lend further support to these discussions by illustrating the lens of social work students, who--in their transitioning from students to practitioners--are perhaps thus more attuned to that 
disconnect between education and practice. IResolving the challenges to SWE in the MENA world may be no only a matter of time, resources, or administration/ management within the classroom and university; the challenges may lay more deeply rooted in the substantive content of SWE itself.

\section{Limitations.}

This study aimed to help fill in gaps about perspectives of students from the MENA region-but it shows only a partial picture, and there are limitations. First, because the research questions focused on students, data were not collected for supervisor, faculty member, or field advisor perspective in the universities where the survey was administered. Second, the survey did not go through a rigorous analysis of reliability and validity, although the survey was reviewed by peers and scholars. Moreover, the 3-point Likert scale was limited; thus, results should be interpreted with caution. Third, nations (within the MENA region), universities (within each nation), and classes (within each university) were not randomly selected, but via snowball sampling and convenience and thus not representative. This limitation could be considered in light of challenges to data collection in the region, particularly on a cross-national scale.

\section{References}

Abd Al-Hamid, I. S. (2003). Students' Problems at the United Arab Emirates University. Journal of Humanities and Social Sciences, 19(1), 37-77.

Abdul Maguid, H. S. (2014). Proceedings from the 27th International Conference of Social Work held in Helwan University: Issues and challenges of social work practicum in developing countries in comparison with developed countries. Helwan, Egypt.

Al-Adayleh, L. M., \& Al-Hadedy, H. T. (2013). Attitudes of social work students at Al-Balqa Applied University towards academic study. Dirasat, Human and Social Sciences, 40(3), 787.

Al-Deeb, M.N. (2005). Proceedings from the 18th International Conference of Social Work held in Helwan University: The Reality of Education in Egypt and Arab Countries and Challenges it Faces for Reform and Modernization from Social Work Perspective. Helwan, Egypt.

Al-Halalat, K. I. (2015). Field Training Obstacles Among Students of The Social Work at the University of Jordan. Dirasat, Human and Social Sciences, 42(1), 1109-1129.

Al-Imam, N. (1998). Field practicum to prepare Social Work Students: Current Situation, Future Vision. Journal of Humanities and Social Sciences, 2(4), 992.

Al-Makhamreh, S. \& Libal, K. (2012). The Middle East: Expanding social work to address 21 st century concerns. In Lyons, K. et al. (Eds.), The handbook of international social work. Sage. 
Al-Makhamreh, S. \& Sullivan, M. (2013). Professionalising social work in Hashemite Kingdom of Jordan: processes and implications. European Journal of Social Work, 16(4), 536-550.

Alsahow, E., Parris, D., Sayed, H., Guest, H., Keidl, T.D., DeOtte, E., Baldridge, S., Slaymaker, R. \& Paris, W. (2019). Interprofessional simulation as an educational tool to address cultural competence in working with Muslim patients in West Texas. Egyptian Journal of Social Work, 7(1), 17-30.

Al-Shuaibi, H. S. (2005). Proceedings from the 18th International Conference of Social Work held in Helwan University: Towards a proposed conceptualization for the required courses of serving the individual at the faculties and departments of social work in Riyadh, Kingdom of Saudi Arabia. Helwan, Egypt.

Al-Zobair, F. S. (2009). Proposed conception to achieve greater quality in social work education at graduate level. Periodical of Social Work Studies and Human Science, 26(3), 1414.

Arseneau, M. S. (2015). The developmental education dilemma in the community college system: The students' point of view (PhD Dissertation). Capella University, United States--Minnesota.

Awawda, A. S. (2011). An evaluative study of the reality of field practicum in Social Work at the Balqaa Applied University from the perspective of students. Journal of the Faculty of Education-Literary Section, 16(1), 382-428.

Baum, N. (2012). Field Supervision in Countries Ridden by Armed Conflict. International Social Work, 55, 704-719.

Cook-Sather, A. (2002). Authorizing Students' Perspectives: Toward Trust, Dialogue, and Change in Education. Educational Researcher, 31(4), 3-14.

Dominelli, L. (2010). Social Work in a Globalizing World. Cambridge: Polity Press.

Ewiess, M. M. (2005). Proceedings from the 16th Annual Conference, Social Work and the Age of Information held in Cairo University: International Social Work Education Volume 1. Fayoum, Egypt.

Faramawy, M. A. (2005). Proceedings from the 18th International Conference of Social Work held in Helwan University: Reform of Social Work Education: Reality and Aspirations. Helwan, Egypt.

Ferguson, K. M. (2005). Beyond Indigenization and Reconceptualization: Towards a Global, Multidirectional Model of Technology Transfer. International Social Work, 48, 519-536.

Hamza, A. (2006). Knowledge requirements of a School Social Worker as Indicator of Quality of Social Work Education. Periodical of Social Work Studies \& Human Science, 21(1), 9-42.

Hassan, S. S. (2010). Requirements for Achieving Quality Education in Group Work Methods in Egypt (Unpublished doctoral dissertation). Fayoum University, Egypt.

Hassanain, S. (2014). Evaluation of the effectiveness of the field practicum program from the standpoint of social work students at Al-Quds University. An-Najah National University Journal for Research (Human Sciences), 28(3), 517-546. 
Holtzhausen, L. (2011). When Values Collide: Finding Common Ground for Social Work Education in the United Arab Emirates. International Social Work, 54, 191-208.

Ibrahim, Q. (2015). Glocalization and International Social Work Education: Concepts, Principles, Education and Practice (1st ed.). Jordan: Dar Al Shorouk for Publishing.

- (2017). Social work education in Arab universities and educators' perceptions. Social Work Education, 37, 78-91.

- (2018). Glocalization and international social work education. A comparative study of Palestine, Jordan, Saudi Arabia, Oman, Yemen, Egypt, Libya and Morocco. International Social Work, 60(6), 1399-1417.

Kokaliari, E., Berzoff, J., Byers, D. S., Fareed, A., Berzoff-Cohen, J., \& Hreish, K. (2016). Teaching Clinical Social Work Under Occupation: Listening to the Voices of Palestinian Social Work Students. Journal of Teaching in Social Work, 36(2), 140-159.

Lammers, W. J., \& Smith, S. M. (2008). Learning Factors in the University Classroom: Faculty and Student Perspectives. Teaching of Psychology, 35(2), 61-70.

Lyngstad, R. (2013). Contextual social work and internationalizing social work education: Two sides of the same story? Journal of Social Work, 13(4), 400418.

Mansour, S. H., \& Hassan, M. A. (2008). Proceedings from the 1st International Conference of Social Work held in Assiut University: Social work education in the light of the labor market variables. Assiut, Egypt.

Megahead, H. A. (2016). Research on Social Work Practice in Egypt and the Arab World. Research on Social Work Practice, 1-8.

Mokhtar, A. A. (2006). Proceedings from the 19th International Conference of Social Work held in Helwan University: Quality Standards in Social Work Education. Helwan, Egypt.

Osei-Hwedie, K., Ntseane, D., \& Jacques, G. (2006). Searching for Appropriateness in Social Work Education in Botswana: The process of developing a Masters in Social Work program in a 'developing' country. Journal of Social Work Education, 25(6), 569-590

Sloan, L. M., Bromfield, N. F., Matthews, J., \& Rotabi, K. S. (2017). Social work education in the Arabian Gulf: Challenges and opportunities. Journal of Religion \& Spirituality in Social Work: Social Thought, 36(1-2), 199-214.

Small, E., Sharma, B. B., \& Nikolova, S. P. (2015). A Pilot Study Evaluating Students' Interest in International Social Work Education. Social Work Education, 34(4), 414-427.

Soliman, H. \& Abd Elmegied, H. (2010). Challenges of Modernization of Social Work Education in Developing Countries: The Case of Egypt. International Social Work, 53(1), 101-114.

See below for Tables 1,2,3. 


\begin{tabular}{||lcr||}
\hline Egyptian Journal of Social Work (EJSW) & http://ejsw.journals.ekb.eg \\
Print ISSN: $2356-9204$ & Online ISSN: 2356-9212 & Vol 9, Issue 1, January 2020 \\
\hline \hline
\end{tabular}

Table 1. Descriptive Statistics on Respondents $(\mathbf{N}=\mathbf{8 1 0})$

\begin{tabular}{|c|c|c|c|c|}
\hline Variables & Categories & $\mathrm{Q}$ & $\%$ & Ranking \\
\hline \multirow{2}{*}{ Gender } & Male & 211 & 26.0 & 2 \\
\hline & Female & 599 & 74.0 & 1 \\
\hline \multirow{3}{*}{ Age } & Less than 25 years & 703 & 86.8 & 1 \\
\hline & 25 to less than 30 years & 99 & 12.2 & 2 \\
\hline & 30 and above & 8 & 1.0 & 3 \\
\hline \multirow{4}{*}{ Marital Status } & Single & 628 & 77.5 & 1 \\
\hline & Married & 172 & 21.2 & 2 \\
\hline & Divorced & 7 & 0.9 & 3 \\
\hline & Widowed & 3 & 0.4 & 4 \\
\hline \multirow{6}{*}{$\begin{array}{l}\text { Degree Awarded } \\
\text { In Social Work }\end{array}$} & Diploma & 21 & 2.5 & 6 \\
\hline & Bachelor of Arts & 345 & 42.6 & 1 \\
\hline & Master of Arts & 67 & 8.3 & 5 \\
\hline & Doctoral, Ph.D. & 130 & 16.1 & 2 \\
\hline & Bachelor + M.A. & 119 & 14.7 & 4 \\
\hline & B.A. + M.A. + Ph.D. & 128 & 15.8 & 3 \\
\hline \multirow{4}{*}{$\begin{array}{l}\text { Studying System in } \\
\text { Social Work Education }\end{array}$} & External & 5 & 0.6 & 3 \\
\hline & Regular & 803 & 99.1 & 1 \\
\hline & Open Education & 2 & 0.2 & 4 \\
\hline & & 810 & 100 & \\
\hline
\end{tabular}


Table 2 Distribution of Student Respondents by Country and University $(N=810)$, listed according to number of students in universities

\begin{tabular}{|c|c|c|c|c|c|c|c|c|}
\hline Country & Universities & $\begin{array}{l}\text { No. of } \\
\text { Students }\end{array}$ & $\begin{array}{l}\text { No. of student } \\
\text { respondents } \\
\text { (N) }\end{array}$ & $\%$ & $\begin{array}{l}\text { Hours } \\
\text { of field } \\
\text { educ. }\end{array}$ & $\begin{array}{l}\text { No. of } \\
\text { Faculty }\end{array}$ & $\begin{array}{l}\text { Year } \\
\text { Est.: } \\
\text { SSW }\end{array}$ & $\begin{array}{l}\text { Year } \\
\text { Est.: } \\
\text { Univ. }\end{array}$ \\
\hline Egypt & Fayoum Univ. & 2824 & 123 & 15.2 & 644 & 101 & 1984 & 1975 \\
\hline $\begin{array}{l}\text { Saudi } \\
\text { Arabia }\end{array}$ & $\begin{array}{l}\text { Al-Imam } \\
\text { Muhammad } \\
\text { Ibn Saud } \\
\text { Islamic Univ. }\end{array}$ & 5870 & 116 & 14.3 & 544 & 54 & 1979 & 1974 \\
\hline \multirow[b]{2}{*}{ Jordan } & Univ. of Jordan & 270 & 44 & 5.4 & 750 & 9 & 1998 & 1962 \\
\hline & $\begin{array}{l}\text { Al-Balqa } \\
\text { Applied Univ. }\end{array}$ & 320 & 39 & 4.8 & 144 & 8 & 1965 & 1997 \\
\hline Yemen & $\begin{array}{l}\text { Sana'a } \\
\text { Univ. }\end{array}$ & 500 & 44 & 5.4 & 700 & 14 & 2004 & 1970 \\
\hline Libya & $\begin{array}{l}\text { Univ. } \\
\text { Tripoli }\end{array}$ & 450 & 56 & 6.9 & 480 & 52 & 1983 & 1957 \\
\hline Kuwait & $\begin{array}{l}\text { Kuwait } \\
\text { Univ. }\end{array}$ & 299 & 71 & 8.8 & 450 & 29 & 1966 & 1966 \\
\hline Oman & $\begin{array}{l}\text { Sultan Qaboos } \\
\text { Univ. }\end{array}$ & 282 & 20 & 2.5 & 240 & 9 & 2001 & 1986 \\
\hline Iraq & $\begin{array}{ll}\text { Univ. } & \text { of } \\
\text { Baghdad } & \\
\end{array}$ & 130 & 72 & 8.9 & 240 & 13 & 1952 & 1949 \\
\hline Morocco & $\begin{array}{l}\text { Sidi } \\
\text { Mohammed } \\
\text { Ben Abdellah } \\
\text { Univ., Fez }\end{array}$ & 60 & 18 & 2.2 & 60 & 6 & 2008 & 1975 \\
\hline
\end{tabular}

\section{Table 3. Results by Domains, Mean Scores and Rank}

\begin{tabular}{|l|l|l|}
\hline Domain & $\begin{array}{l}\text { Mean scores for all } \\
\text { items in respective } \\
\text { domains }\end{array}$ & Rank \\
\hline $\begin{array}{l}\text { First theme: Externally-oriented real-world application of social work } \\
\text { education }\end{array}$ & 1 \\
\hline Societal recognition of the profession & 2.35 & 2 \\
\hline Field practicum & 2.33 & 3 \\
\hline Social workers post-graduation & 2.32 & 4 \\
\hline Professional practice institutions & 2.31 & 5 \\
\hline Second theme: Curriculum & 2.30 & \multicolumn{2}{|l|}{} \\
\hline Curriculum & \multicolumn{2}{|l|}{ social work } \\
\hline $\begin{array}{l}\text { Third theme: Internally-oriented } \\
\text { education }\end{array}$ & university factors to & 6 \\
\hline Methods of teaching & 2.29 & 8 \\
\hline The university text book & 2.29 & 9 \\
\hline The quality of the library & 2.28 & 10 \\
\hline Quality of student assessment & 2.27 & 7 \\
\hline Faculty members & 2.25 & \multicolumn{2}{|l|}{} \\
\hline
\end{tabular}

